\title{
Optimizing Academic Education: Philosophies for Creative Quality Lives
}

\author{
Meysam Nikkhah, Akbar Nikkhah \\ Department of Animal Sciences, University of Zanjan, Zanjan, Iran. \\ Email: nikkhah@znu.ac.ir \\ Received August 18 th $^{\text {th }}$ 2011; revised September 24 $4^{\text {th }}$, 2011; accepted September 30 2011.
}

\begin{abstract}
The objective is to delineate postmodern learning and mentoring interrelation, elite-thinker-generating skills development, optimum mentor-staff-mentee interactions, mentors' soci-economic security, and advanced mentorship evaluation strategies. Education is a foremost cause to find merits in life. Advancements in science and technology result from improved education. For creative science education to achieve optimums, it must be improved globally. Science and technology mentors must be continually educated and updated with artistic and creative mentorship skills. Effective education will optimize social interactions. Efforts should be made to optimize mentor-staff-mentee interactions in academia to effectively facilitate education and improve science quality. Effective mentorship requires making policies for effective management of mentors' time and socio-economic life. Theoretical and applied aspects in different majors need to be educated in integrated manners to generate multiple perspectives. Focusing on a single science without appreciating the multiple nature of science will no longer advance scientific accomplishments in the postmodern era. Mentees should be directed to gain expertise in multiple sciences in ways an artist gains excellence in multiple arts. Harmony makes higher quality arts, science and life. A devastating failure would be producing follower graduates who despite having high scores in written tests are unable to mentor, design, direct, conduct, and conclude experiments that aim to sustain and advance science. Postmodern mentees are to be provided with opportunities to simultaneously act as mentor and mentee to appreciate their unique responsibilities. Improved education will improve social economics and human life quality worldwide.
\end{abstract}

Keywords: Science, Education, Mentorship, Academia, Postmodern

\section{Introduction}

Effective education leads human life. Education systems quality determines human life quality. From birth to death, human is exposed to an environment whose education properties determine human's lifespan accomplishment. As such, advancements in the science of science education is under greatly increasing research and policy-making focuses (Alberts, 2008, 2009a, 2009b, 2009c). Education for sustainable future will not be less important than food for continuing life (Nikkhah, 2011a). The primary objective of this perspective article is to delineate postmodern learning and mentoring interrelationships, elite-thinker-generating skills development, optimum mentor-staff-mentee interactions, mentors' soci-economic security, and advanced mentorship evaluation strategies. These academic philosophies will all require deserving thought, time, and financial investments to optimize creative life qualities in societies worldwide.

\section{Postmodern Learning-Mentoring Interrelations}

Learning is a mental process with unique interacting elements. Among factors affecting learning is mentor and mentorship quality. More important than transferring knowledge is to directly and indirectly educate mentees how to effectively supervise and manage the education phenomenon. These duties equip mentees with skills to take initiatives in confronting real life challenges and develop solutions instead of blindly following others and staying apathetic. This systematic education promotes originality, innovation, and creativeness, and discourages transcription (Nikkhah, 2011b). Mentorship patterns should match optimum learning patterns to prove most productive. Harmonic learning-mentoring tasks will optimize professsional communication skills (i.e., spoken, written, aural) and will generate elite speakers, listeners, and writers. These skills must be acquired thoroughly before any advancement in science and technology can make it to people's lives to improve life quality. The communication skills are means whereby science and technology are created, expanded, disseminated, and applied. While the interactive sophisticated mutual (mentormentee) mentorship practices replace one-way teaching, the above skills will develop in a timely manner. Such a communal learning involves challenging mentorship principles to create and expand capacities for excellence in communication. As a result of creating new capacious talents, science education will continue to glorify in many aspects that will contribute to improving science and life qualities (Nikkhah, 2011c).

\section{Discovering, Valuing, and Expanding Elite Mentorship Skills}

Motivation fuels progress in science and technology. The key to create and maintain motivation is discovering and valuing creative insights. Creativeness is a potential to realize and secure. Mentees can be mentored to develop and expand creativity. Discovering and expanding creative talents is an obligation for the third millennium's science servants. The most fruitful science is the one that discovers and creates talents who can discover and create higher quality talents. Equipment, devices, technologies, techniques, and publications are not considered the foremost science products in the postmodern era. The postmodern science requires minds and philosophies that will 
progressively facilitate generating such science products (Nikkhah, 2011d). The postmodern science education focuses first and foremost on the cause. The effect will result automatically. The cause includes elite mentors who advance elite mentorship skills. The cause includes elite distinguished thinkers who are prepared to be challenged to generate elite thinkers of the coming generations. Creative motivation facilitates the multi-nature complex of science education. Mentors should get mentees involved in education. Mentors must not let mentees to remain only learners. Science will achieve the highest potentials should mentees get involved with mentorship duties very early during the learning process. The postmodern science will not look into educators as simply knowledge transporters and will not consider learners as followers or knowledge seekers and trancriptors. Teachers and learners are in no ways mobile knowledge careers. They must synthesize and expand skills to transform knowledge into insights and educate others such skills (Nikkhah, 2011a). Knowledge can improve life quality only when it is transformed into insightful real life strategies (Nikkhah, 2011b). Therefore, learning is only a trivial part of the whole mentorship collection whose main component is creating the capacity to educate others. Learning is not saving intact information in mind. Learning is a beginning to lead a mentee to become a mentor. Effective learning can be guaranteed only when effective mentorship skills are adequately developed.

\section{Teacher Education for Optimum Mentorship Strategies}

The beginner educators are to be profoundly educated on moral constituents of the delicate mentorship commitment. It must be continually emphasized that the most significant entity of any society is the quality of its educators. Superior education enables constructing superior social, economic, and cultural properties. Higher quality education, thus, leads to intellectual and superior oral and aural communications. These benefits will ease life affairs and improve life quality and satisfaction. The effects of such systematic education will be beyond regions and will involve global science education (Nikkhah, 2011c, 2011d). It is inferred that some of the current global challenges in sustaining a quality life for the world citizens result from education deficiencies in certain regions. Thus, an effective approach for optimizing global life quality is to improve regional science educations in harmonic manners.

\section{Optimizing Mentor-Staff-Mentee Interactions}

Three main professional tasks are necessary to optimizing the academic science education. These include mentors' advising programs, mentees' outspoken expression of challenges towards mentorship, and staff's management of academic documentation and paperwork. Globally, the latter does not seem to receive deserving attention in many instances. Basically, staff help bridge mentors' and mentees' minds. As such, they must periodically receive systematic education to profoundly appreciate their standing in academia and their critical role in facilitating effective science education. The unique role distinguishes academic official staff from counterparts in non-academic environments. Optimizing the three-way communication among mentors, mentees and staff has been a major challenge in academia. Education for improving communication among the three groups is a foundation upon which mentees' future societal communication skills will be built. Getting through an effective communication with mentors and staff in academia will equip mentees with proficient skills to overcome management challenges in science education in either academia, industry, or any society they will work in. Another main challenge is to establish professional communications between mentors and mentees (Allen et al., 2011). Questions, suggestions, critiques, and any thought exchange between mentors and mentess are to be highly persuaded and frequently exercised. In the postmodern systems of science education, mentors welcome mentees' challenges of mentorship because this will simply grant mentees with pathways for gaining mentorship experience and will enable them to practically appreciate the true art of mentorship (Nikkhah, 2011b). Silence, one-way teaching, and challengefree thought expression are considered toxic to any dynamic education system and must be discouraged. Realistically, always expected from mentess is not the optimally professional communication, which is always expected from mentors. Mentors, thus, should acknowledge and grant the opportunity to mentees to learn from scenarios they face during their learning experience. The program will not repeat, and thus, should be maximally utilized to enhance mentorship efficiency for mentors, mentees, education systems, founders, governments, and ultimately people.

\section{Socio-Economic Security of Postmodern Science Educators}

Science education is a delicate process that needs to be conducted under mentally focused and socio-economically stable conditions (Weinberg, 2011). External factors that weaken the motivation induction process will dramatically reduce outcomes quality in any education setting. Special economical and social promotion policies need to be innovated to support, maintain and enhance mentors' abilities in inducing motivation in mentees towards science and technology. Such policies will strengthen mentees' beliefs in the power of science for transforming human lives. The major part of a promotion policy lies in its social security. Very often, financial promotions are highly insufficient in persuading mentors to induce motivation in mentees for science. Social security is defined as social significance. Mentors must feel their character socially significant before they can be persuaded to make enormous efforts to enhance their mentorship skills. Such a social significance ought to be properly recognized and appreciated by policy-makers and governors (Nikkhah, 2011e). Such recognitions will make mentors increasingly appreciative of their outstanding position in the scientific and economical growth of the world nations. As a result, mentor will make further efforts to ensure generating upcoming mentors with capabilities to keep the science ball rolling.

\section{Integration of Theoretical and Applied Sciences: Revisited Policy-Making for Mentees Evaluation}

In all science majors, theoretical and applied branches are highly integrated. Basically, no science major can be solely theoretical or applied. What makes a given science theoretical or applied concerns with how, when, where, and within which education system it is utilized. Also, a science can under no circumstances be absolutely theoretical or applied. It can rather 
be proportionally either one. Unifying theoretical and applied aspects of science will strengthen the interactions of academia and industry. The resulting graduates will be better prepared to work through challenges of the industry. Also, the systematic integration of theoretical and applied sciences will increase mentors' inspiration in supervising the learning process. The enthusiasm will improve science perception and minimize ambiguities. In addition, such a mentorship passion will better mentor-mentee interactions and their task satisfaction. Integrating a multitude of sciences with theoretical and applied aspects resemble playing a multitude of music instruments in an orchestra. The harmony among the instruments will create statesof-art that are greatly superior to when each instrument is played alone. Science would similarly benefit from such an influential harmony because science is an art and scientists are artists (Nikkhah, 2011b). Thus, pursuing multi-science perspectives should be encouraged. Brain cells process information more effectively when an increased enthusiasm results from an amalgamation of different sciences (Berns \& Moore, 2011; Berns et al., 2011; Nikkhah, 2011c). As a result, global insights into the ultimate goals of progress in science and technology for improving human life quality will be optimally developed in mentees' minds. Optimal understanding of the global science philosophy will be a commitment and will mature with mentees' appreciation of such multi-science learning strategies.

Mentee evaluation programs should not be limited to only written examination of theoretical sciences. This would only test mentees' memory and photocopying practices that are not praiseworthy in the postmodern science education. Memorizing and delivering the same information given by the teacher is not an art. Receiving insights from the mentor, contemplating, discussing, and proposing innovative proposals that lead to new experiments and discoveries are among the postmodern duties of mentees. In testing mentees' challenged learning and analytical skills for both theoretical and applied aspects, they are expected to independently direct and conduct experimental or thought designs. This will prove their capability in contemplating, tackling, and overcoming real-life problems as applied to their major. Communication skills will expand and be tested when mentees conclude the designs with public presentation and data dissemination in both oral and written. A recent study suggested that mentees who experience both teaching and research perform superior in designing new experiments compared to those who focus only on research (Feldon et al., 2011). Thus, what are expected from an upcoming mentor must be exercised in mentees' graduate programs. Ultimately, any postmodern scientist must become proficient in research design, data collection, analysis, communication, and distribution to be of utmost benefit to science and society. These are undoubtedly the most determining duties of a scientific task. Science must generate producers and not consumers. Such procedures would ensure generating upcoming insightful mentors instead of lingering students who do not initiate confronting and surmounting life challenges. The most devastating failure of an education system would be a collection of follower graduates who despite having high scores in written tests are unable to mentor, design, direct, conduct, and conclude experiments that aim to advance science and improve life quality. Demonstrating such skills is not suddenly expected at the termination of mentees' studies, but they are trained to gain those skills throughout their program. This preparation will involve proficiencies in definitivedecision-making, collaborative-working, and independent-mentoring as graduates start their professional activities. Optimally, students should thus be provided with opportunities to simulta- neously act as mentor and mentee to experience and appreciate their responsibilities. That will help optimize their communication skills in academia and industry in contributing to generating distinguished elite mentors.

\section{Implications}

This perspective article delineated postmodern learningmentoring interrelations, discovering and sustaining elite mentorship capacities, teacher education for optimum mentorship, and mentor-staff-mentee interactions. The socio-economic security for science educators, fundamental integration of theoretical and applied sciences, and revisited mentee evaluation programs were described. With most deserving thought, time and financial investments in the above philosophies, elitemanagement projects and elite-manager development will prevail as a creative commitment in academia. These education philosophies will improve social economics and creative life quality worldwide.

\section{Acknowledgements}

Nature for its inspiring life expressions deserves the highest acknowledgments.

\section{References}

Alberts, B. (2008). Considering science education. Science, 319, 1589. doi:10.1126/science. 1157518

Alberts, B. (2009a). Making a science of education. Science, 323, 15. doi:10.1126/science.1169941

Alberts, B. (2009b). Redefining science education. Science, 323, 437. doi:10.1126/science. 1170933

Alberts, B. (2009c). Science for science. Science, 324, 13. doi:10.1126/science.1174131

Allen, J. P., Pianta, R. C., Gregory, A., Mikami, A. Y., \& Lun, J. (2011). An interaction-based approach to enhancing secondary school instruction and student achievement. Science, 333, 1034-1037. doi:10.1126/science. 1207998

Berns, G. S., \& Moore, S. E. (2011). A neural predictor of cultural popularity. Journal of Consumer Psychology, in press. http://www.sciencedirect.com/science/article/pii/S1057740811000532 doi:10.1016/j.jcps.2011.05.001

Berns, G. S., Capra, C. M., Moore, S., \& Noussair, C. (2010). Neural mechanisms of the influence of popularity on adolescent ratings of music. Neuroimage, 49, 2687-2696. doi:10.1016/j.neuroimage.2009.10.070

Feldon, D. F., Peugh, J., Timmerman, B. E., Maher, M. A., Hurst, M., Strickland, D., Gilmore, G. A. \& Stiegelmeyer, C. (2011). Graduate students' teaching experiences improve their methodological research sills. Science, 333, 1037-1039. doi:10.1126/science.1204109

Nikkhah, A. (2011a). Structuring science education in the New Millennium: Authorizing a succeeding integrity. Progress in Education, New York, NY: Nova Publishers Inc.

Nikkhah, A. (2011b). Science education of the new millennium: Mentorship arts for creative lives. Creative Education, in press. doi:10.4236/ce.2011.24048

Nikkhah, A. (2011c). Frontiers in global science designation for quality lives. Scientific Research and Assays, in press.

Nikkhah, A. (2011d). Postmodern science edification philosophy. Open Journal of Philosophy, in press. doi:10.4236/ojpp.2011.11007

Nikkhah, A. (2011e). Postmodern governments and science education. Journal of Public Administration and Governance, 1, 71-74. doi:10.5296/jpag.v1i1.702

Weinberg, S. (2011). Nobelist steven weinberg calls for bigger science, more taxes. ScienceNOW. URL (last checked 6 June 2011) http://news.sciencemag.org/sciencenow/2011/06/nobelist-steven-wei nberg-calls-f.html?etoc 